\title{
QUANTIFYING THE SPATIO-TEMPORAL VARIABILITY OF WATER QUALITY IN AN URBANIZING PERENNIAL MEDITERRANEAN RIVER: THE CASE OF THE BEIRUT RIVER
}

\author{
SANIA EL-NAKIB, IBRAHIM ALAMEDDINE, MAJDI ABOU NAJM \& MAY MASSOUD \\ Maroun Semaan Faculty of Engineering and Architecture, Department of Civil and Environmental Engineering, \\ American University of Beirut, Lebanon
}

\begin{abstract}
Rivers are increasingly being subjected to increased anthropogenic pollution stresses that are undermining their designated-uses and negatively affecting sensitive coastal areas. In this study, the water quality of the Beirut River, a poorly monitored seasonal Mediterranean River, is quantified. Water quality samples were collected on a regular basis over two consecutive years (2016 and 2017) from four sampling sites that represent a gradient of increased urbanization. The spatio-temporal variability of the physio-chemical ( $\mathrm{pH}$, Total Suspended Sediment (TSS), Nitrates-nitrites $\left(\mathrm{NO}_{\mathrm{x}}\right)$, sulfates $\left(\mathrm{SO}_{4}\right.$ 2), Total Phosphorus (TP), Total Nitrogen (TN), temperature, conductivity, chemical oxygen demand (COD) and bio-chemical oxygen demand (BOD)) and biological (fecal coliform and total coliform) pollution levels were statistically analysed in an effort to better understand the contribution of point and non-point pollution sources. The results showed significant yearly as well as seasonal variability and a high correlation between the measured pollution levels and river flow levels. Spatially, pollution levels appeared to correlate well with the urbanization levels in the basin. Future work will focus on modeling and further characterizing the pollutant loads reaching the Beirut River Basin. It is hoped that this study will give decision makers a better understanding of the water quality in the Beirut River and thus facilitate the development of an integrated comprehensive and transparent river basin management plan. Keywords: spatial variation, temporal pattern, water quality, Beirut River, Lebanon.
\end{abstract}

\section{INTRODUCTION}

Anthropogenic induced alterations are the primary drivers for modifying environmental systems and nutrient cycles, especially in freshwater bodies [1], [2]. Worldwide freshwater ecosystems, including rivers, have been degraded by the discharge of anthropogenic landbased sources of pollution [3]-[6]. The United Nations estimated that $90 \%$ of domestic wastewater and $70 \%$ of industrial wastes were discharged untreated into water bodies [7]. Rivers are an important freshwater resource that is used for drinking, irrigation, and industrial purposes [8]. Yet, their ultimate use is often constrained by their water quality [9], [10]. Several studies has linked the water quality of rivers to the landuse/landcover within their basins [11]-[13]. In addition, contamination levels in rivers are often affected by seasonal variability and changes to river flows [14], [15]. An effective river basin management plan is contingent on collecting data on water quality and identifying the main sources of pollution [16]-[18]. Studies undertaken in Lebanon have shown that most rivers have high levels of contamination; the main sources of pollution have been attributed to the discharge of untreated municipal wastewater and the excessive use of fertilizers [19]-[20]. In this study, the spatio-temporal variability in the water quality of Beirut River, a poorly monitored seasonal Mediterranean River, were assessed in an effort to determine sources of pollution and propose mitigation and management measures. 


\section{METHODOLOGY}

\subsection{Study area}

The Beirut River springs from the Western slopes of Mount Lebanon at an altitude of $1890 \mathrm{~m}$. The river flows westwards for about twenty kilometres before discharging in the Mediterranean Sea. The total area of Beirut River watershed is $228 \mathrm{~km}^{2}$. More than 300,000 people reside within its boundary. Like most Lebanese rivers and many Mediterranean rivers, the Beirut River is seasonal and dries out in the summer. In this study, four sampling locations were selected along the Beirut River. The locations of the sampling station are represented in Fig. 1. Table 1 summarizes the main landuse/landcover for the area draining into each station. S1 is located in a pristine area dominated by pine forests. Station S2 is located below a major town and is in close proximity to a composting facility and a concrete masonry blocks plant. Station S3 is located in an agricultural area with some touristic activities. Nevertheless, the station is just downstream of a wastewater effluent pipe collecting raw sewage from several suburban areas in the basin. The area in the vicinity of S4 is largely industrial and degraded. This section of the river is impacted by the open discharge of untreated wastewater and the open dumping of solid waste. Overall, the land cover of the watershed varies significantly with elevation; the headwaters of the basin are largely agricultural and rural, while the lower sections are heavily urbanized and industrialized.

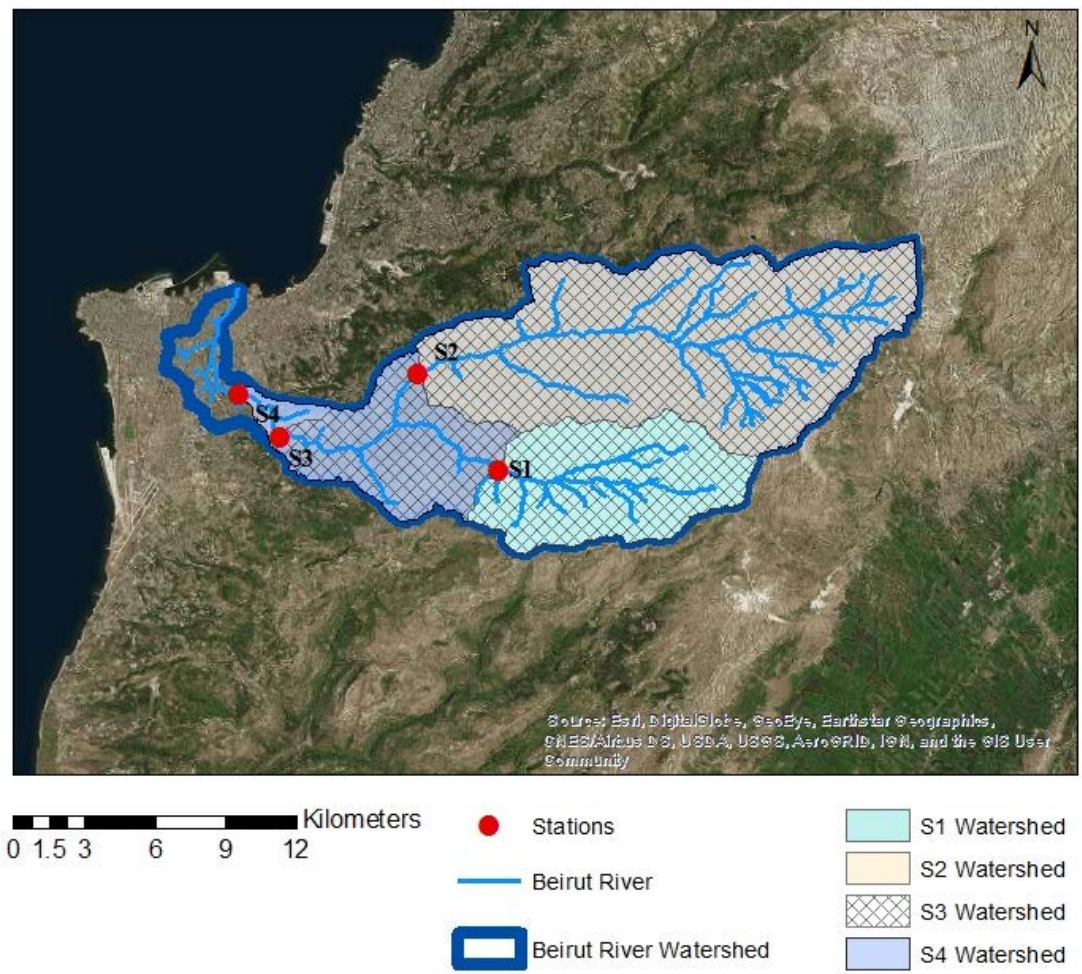

Figure 1: Map of the sub watershed and the location of the sampling: (S1) Rwaysit El Ballout; (S2) Jaamani; (S3) Daychounyeh; and (S4) Jisr El Basha. 
Table 1: General description of the four sub-watersheds along with the entire watershed.

\begin{tabular}{|l|c|c|c|c|}
\hline Station & $\begin{array}{c}\text { Watershed area } \\
\mathrm{km}^{2}\end{array}$ & Population & $\begin{array}{c}\text { Agricultural area } \\
\mathrm{km}^{2}\end{array}$ & $\begin{array}{c}\text { Urban area } \\
\mathrm{km}^{2}\end{array}$ \\
\hline S1 & 49 & 13,196 & 3.64 & 6.84 \\
\hline S2 & 126 & 31,717 & 14.31 & 15.69 \\
\hline S3 & 213 & 71,401 & 20.58 & 45.79 \\
\hline S4 & 216 & 83,163 & 21.84 & 56.90 \\
\hline Beirut River & 228 & 199,419 & 22.97 & 61.88 \\
\hline
\end{tabular}

\subsection{Water quality sampling}

Water quality sampling was conducted between 2016 and 2017. Water samples from the four stations were collected on a weekly basis when the river was flowing. Physico-chemical and biological parameters were determined by the methods shown in Table 2. Temperature, $\mathrm{pH}$, and conductivity measurements were performed on site. Moreover, water quality samples were transported to the Environmental Engineering Research Center and Laboratories (EERC) at the American University of Beirut (AUB) and stored at $4^{\circ} \mathrm{C}$ for further analysis. The analysis determined total suspended solids (TSS), nitrogen (as total nitrogen (TN) and nitrite and nitrate $\left(\mathrm{NO}_{\mathrm{x}}\right)$ ), phosphorous (as total phosphate (TP) and as ortho-phosphate PO4), sulfates, chemical oxygen demand (COD), and biochemical oxygen demand (BOD5). Furthermore, biological tests were done to assess the total and fecal coliform concentrations at the four sites.

Table 2: Adopted water quality analysis methods. (Source: Rice and Bridgewater [21].)

\begin{tabular}{|c|c|c|c|}
\hline \multirow[t]{2}{*}{ Parameters } & \multicolumn{3}{|l|}{ Adopted method } \\
\hline & Quality indicators & Method & Method number \\
\hline \multirow[t]{3}{*}{ Physical } & $\mathrm{pH}$ & Electrometery & $4500-\mathrm{H}+\mathrm{B}$ \\
\hline & Conductivity & Electrometery & $9050 \mathrm{~A}$ \\
\hline & Total suspended solids (TSS) & Filtration & 2540-B \\
\hline \multirow[t]{8}{*}{ Chemical } & Chemical oxygen demand & Reactor digestion & $5220-\mathrm{D}$ \\
\hline & Biochemical oxygen demand & Respirometry & 5210-B \\
\hline & Nitrate & Colorimetry & 4500-NO3-B \\
\hline & Nitrite & Colorimetry & $4500-\mathrm{NO} 2-\mathrm{B}$ \\
\hline & TN (Total Nitrogen) & TNT Persulfate Digestion & 10071 \\
\hline & Phosphate & Colorimetry & 4500-P.B \\
\hline & TP (Total Phosphorus) & Acid Persulfate Digestion & 4500-P.B\&E \\
\hline & Sulfate & Spectrophotometrically & 10200 H.2 \\
\hline Biological & $\mathrm{TC} / \mathrm{TF}$ & Membrane filtration & $9222 \mathrm{~B} / 9222 \mathrm{D}$ \\
\hline
\end{tabular}




\subsection{River flows}

Flow measurements for the Beirut River dating back to 2009 were provided by the Litani River Authority (LRA). LRA provided flow measurements for three points (S2, S3 and S4), while the flow at $\mathrm{S} 4$ was measured concurrently with the water quality sampling efforts using an electromagnetic flow meter, the Hach FH950 flow meter. The choice of the FH950 was based on its ability to measure flow in streams with shallow depth as is the case for the Beirut River in the dry season. Flows were estimated based on the ISO 748:2007 standards for the mid-section method. Note that a regression equation was developed to estimate the flow at S1 from the flow recorded at S2 (eqn (1)). The model was able to predict $79 \%$ of the variability in the observed flow at S1. It is worth mentioning that between May and October there was no flow in the river at all four stations.

$$
\sqrt{(Q)_{S 1}}=0.25+0.55 \sqrt{(Q)_{S 2}}+0.3 \cos \left(\frac{2 \pi T \text { sample }}{365}\right) ; \varepsilon
$$

where:

$\sqrt{(\mathrm{Q})}$ : Square root transformation of flow $\cos (2 \pi T$ sample/365): Seasonal factor determined as a function of the cosine of the time of sampling; Tsample is the sampling date starting with April 1, 2016 (April $12016=1) \varepsilon$ : Residual error of the model; $\varepsilon \sim \mathrm{N}(0,0.21)$.

\subsection{Statistical analysis}

Correlations (Spearman's rank correlation) between the different water quality parameters were first determined and assessed for their statistical significance its significance between the measured parameters. Additionally, repeated measure ANOVA was performed to test for the significance of spatial variability with regards to the observed water quality. Note that all concentrations were log transformed to achieve normality. This was followed by a multiple comparison test using Tukey's method to identify differences of significance between pollutant concentrations and sampling stations. As for the temporal variation, the parametric t-test and the non-parametric Wilcoxon test were used to assess observed variation between the dry and wet season. A two-way ANOVA was conducted to investigate concurrently the effects of both spatial and temporal variations on pollutant concentration. The potential for an interaction between location and seasons was also assessed. Note that all the statistical tests were conducted at the $95 \%$ confidence level $(\alpha=0.05)$. All statistical analysis were performed using the R software [22].

\section{RESULTS AND DISCUSSION}

Most of the water quality parameters tested at the four sampling stations were in violation of the Economic Commission for Europe (ECE), International Commission for the Protection of the Danube River (ICPDR), European Standards (EU), and the United States Environmental Protection Agency (USEPA) Ecoregion III ambient water quality standards, except for $\mathrm{pH}$ and $\mathrm{SO} 4$ as shown in Figs 2 and 3. As can be seen in the figures, concentrations tended to increase moving from the upstream sections of the river down to the downstream sections. The highest concentrations of most parameters were observed at S4 or S3. The median levels of TN at S4 exceeded the ECE water quality standards $(0.3 \mathrm{mg} / \mathrm{L})$ by approximately 15 times, the ICPDR standards $(1.5 \mathrm{mg} / \mathrm{L})$ by approximately 3 times, and the USEPA standards $(0.38 \mathrm{mg} / \mathrm{L})$ by approximately 12 times. The median TN concentrations at S1 and S2 were found to exceed the ECE, ICPDR and USEPA standards by 7, 1.4, and 5 times respectively. The median TN concentrations was found to statistically differ across the 

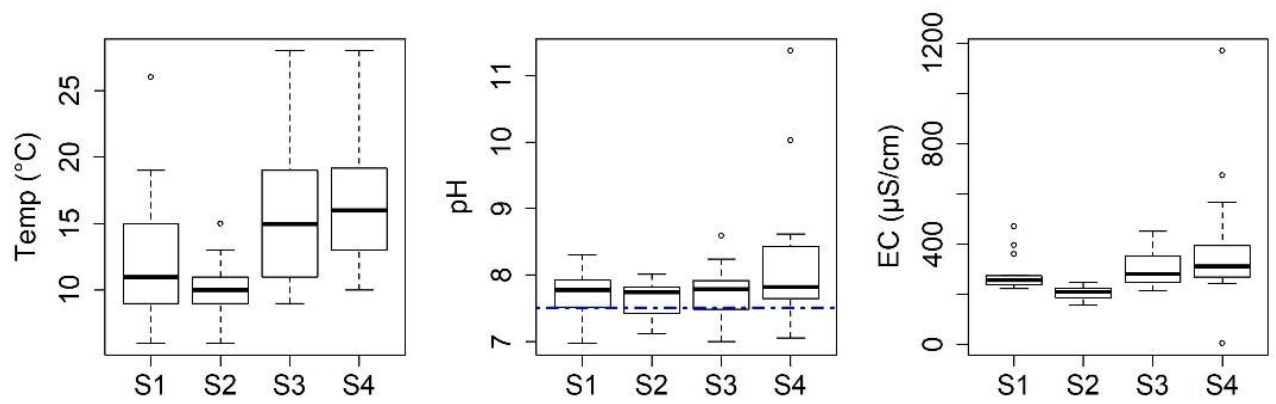

Figure 2: Spatial variation of temperature (temp), $\mathrm{pH}$ and electric conductivity (EC) in Beirut River. Dotdash blue line $=$ EU standard limit.
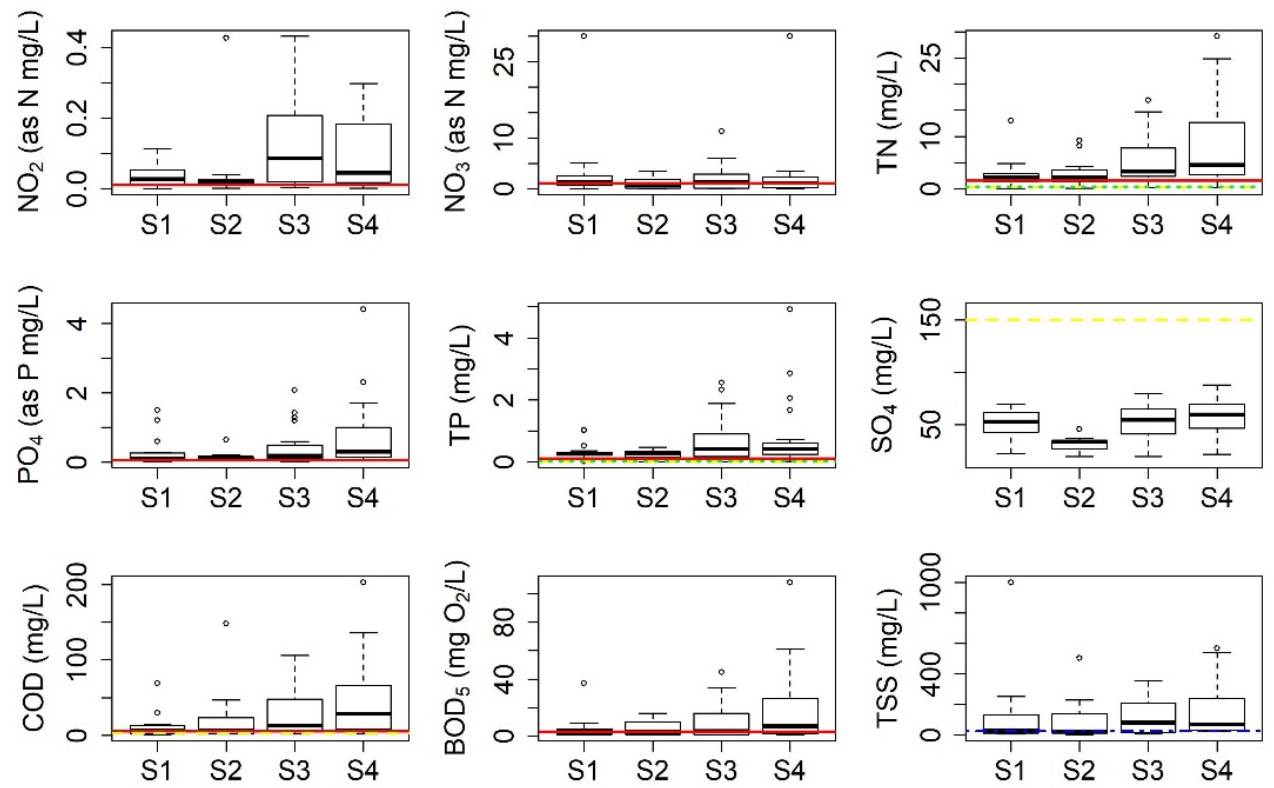

Figure 3: Spatial variation of $\mathrm{NO}_{2}, \mathrm{NO}_{3}, \mathrm{TN}, \mathrm{PO}_{4}, \mathrm{TP}, \mathrm{SO}_{4}, \mathrm{COD}, \mathrm{BOD}$ and TSS in Beirut River. Solid red line = ICPDR; dashed yellow line $=$ ECE; dotted green line $=$ $\mathrm{EPA}$; and dotdash blue line $=\mathrm{EU}$. For $\mathrm{NO}_{2}$ and $\mathrm{NO}_{3}, \mathrm{ICPDR}$ and $\mathrm{ECE}$ have the same standard limits.

four stations (ANOVA, p-value 0.01). According to the Tukey multiple comparison test, statistical differences were observed between S1 and S4 and between S1 and S3 (Tukey, pvalue 0.002 and 0.04 respectively). TN concentrations at S4 and S3 were approximately two times greater than those at S1. Similarly, the measured TP concentrations were found to exceed the standards consistently across the four sampling stations. The median levels of TP at S4 and S3 were 40 times higher than the ECE standard limits $(0.01 \mathrm{mg} / \mathrm{L}), 3$ times higher 
than the ICPDR standard limits $(0.1 \mathrm{mg} / \mathrm{L})$, and 18 times higher than the USEPA standard $(0.0218 \mathrm{mg} / \mathrm{L})$. At S1 and S2, median TP concentrations exceeded the ECE, ICPDR, and USEPA standard limits by approximately $25,1.6$, and 10 times respectively. The observed TP concentrations didn't show a significant difference across the four stations (ANOVA, pvalue 0.1). As for TSS levels, the highest levels were recorded at S3 with a median concentration of $77 \mathrm{mg} / \mathrm{L}$. This value was approximately 3 times larger than the median values recorded at S1 and S2. This is due to the sudden change in landuse-landcover around that station, where the basin transitions from a heavily forested region into a densely urban landuse. However, TSS concentrations were not found to be significantly different across the four stations (ANOVA, p-value 0.08). This is due to the large within group variability in TSS levels at each site. Sulfate concentrations didn't exceed the water quality standards at all sampling occasions. Yet, difference in sulfate concentrations was noted across the three stations (ANOVA, p-value $<0.05$ ). Levels at S4, S3, and S1 were found to be significantly higher than those recorded at S2 when performing the multiple comparison test (Tukey, pvalues $<0.05)$.

COD concentrations at $\mathrm{S} 3$ and $\mathrm{S} 4$ were 3 and 8 times higher than the ECE water quality standard $(3 \mathrm{mg} / \mathrm{L})$ respectively. These concentrations were also 2 and 5 times higher than the ICPDR standard $(5 \mathrm{mg} / \mathrm{L})$, respectively. Median COD levels at the uppermost stations (S1 and S2) only exceeded the water quality standards marginally. Note that the area surrounding S3 and S4 is heavily industrialized and open dumping of wastes is a common practice. The difference in concentration between the four stations was significantly different (ANOVA, $\mathrm{p}$-value $<0.05$ ). Levels at S4 were found to be significantly higher than those recorded at S1, when performing the multiple comparison test (Tukey, p-values $=<0.05$ ). This is to be expected as the area around S4 is heavily industrialized, with many factories dumping their wastewater effluents untreated immediately upstream of that site. With respect to BOD, the median level at $\mathrm{S} 4$ was $7 \mathrm{mg} \mathrm{O} / \mathrm{L}$, which exceeds the $3 \mathrm{mg} / \mathrm{L}$ standard level set by ICPDR. Note that even in the upper sections of the river (S1 and S2), the median BOD levels exceeded the standard. No significant difference of BOD concentrations across the four sampling sites was shown (ANOVA, p-value 0.4). This highlights that municipal wastewater pollution is a problem common to all sections of the river basin. The global impact of wastewater discharge on the river water quality was further highlighted by the fact that the total and fecal coliform bacteria counts across the 4 stations were found to be too numerous to count even when 1:100 dilution was implemented. The $\mathrm{pH}$ values ranged from 6.97 to 11.38 . Levels of $\mathrm{pH}$ showed significant difference across the four stations (ANOVA, p-value 0.009), whereby the observed values at S4 were significantly higher than those at S3 (Tukey, p-value $<0.05$ ). As for the electric conductivity measurements, they ranged between 3 to $1170 \mu \mathrm{S} / \mathrm{cm}$. No statistical difference was noted across the four stations (ANOVA, p-value 0.9).

Overall, the effects of the changing landcover/landuse on the measured river water quality was apparent with a deterioration in the water quality moving from the upstream reaches of the river downstream to its discharge point. Pollution levels were found to significantly increase around the regions that saw a rapid increase in urbanization and a drop in forested land.

These results are in agreement with other studies that have shown that in developing countries a strong positive correlation exists between the percent cover of densely urbanized areas, industrial zones, and agricultural lands on one hand and riverine pollutant levels on the other [14], [23]-[25].

Seasonal variations in pollution levels within the Beirut River basin were assessed by comparing concentrations between the wet and dry seasons (Figs 4 and 5). Overall most of the physiochemical and biological parameters were found to be higher in the dry season as 

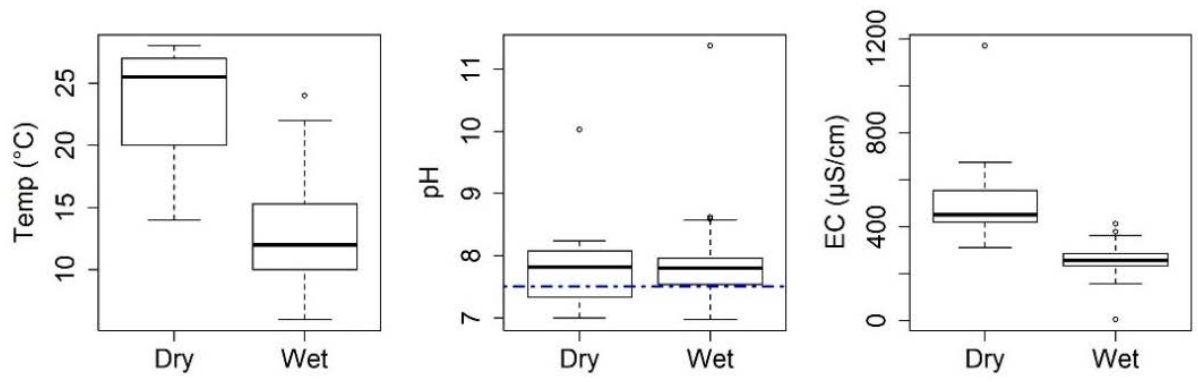

Figure 4: Temporal variation of temperature (temp), $\mathrm{pH}$ and electric conductivity (EC) in Beirut River. Dotdash blue line $=$ EU standard limit.
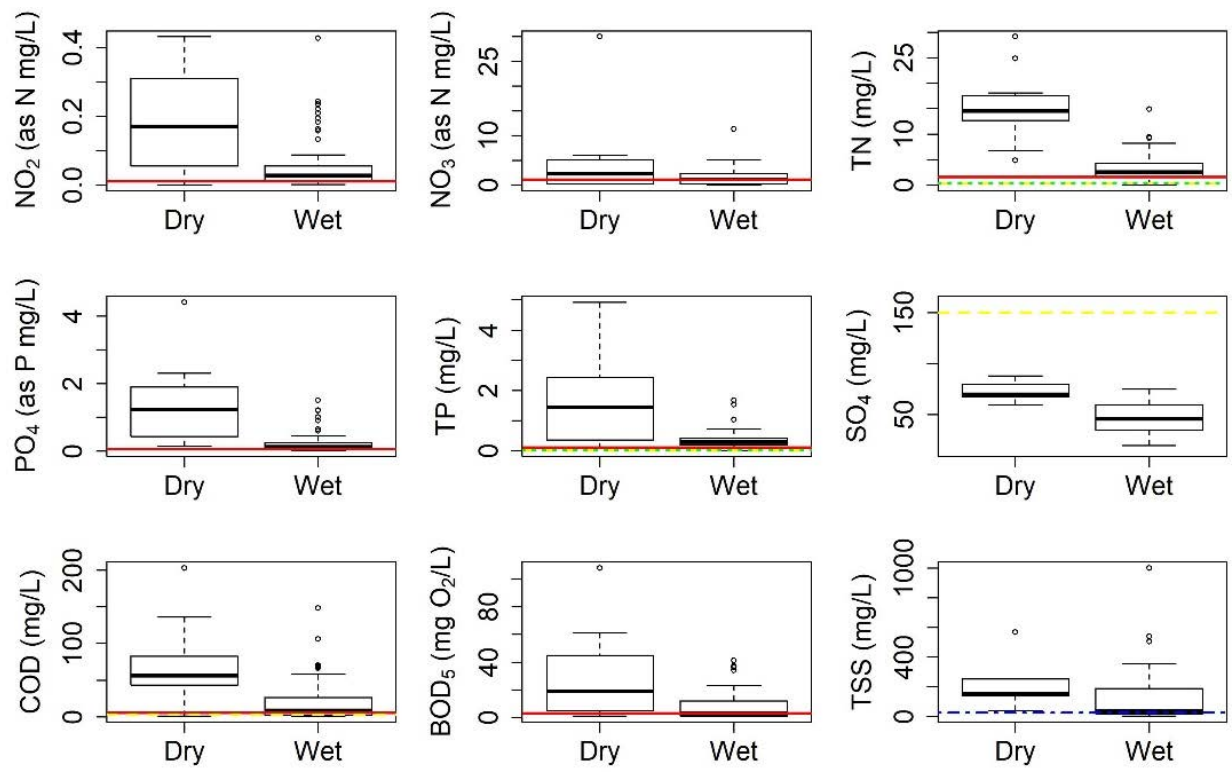

Figure 5: Temporal variation of $\mathrm{NO}_{2}, \mathrm{NO}_{3}, \mathrm{TN}, \mathrm{PO}_{4}, \mathrm{TP}, \mathrm{SO}_{4}, \mathrm{COD}, \mathrm{BOD}$ and TSS in the Beirut River. Solid red line = ICPDR; dashed yellow line $=\mathrm{ECE}$; dotted green line $=\mathrm{USEPA}$; and dotdash blue line $=\mathrm{EU}$. For $\mathrm{NO}_{2}$ and $\mathrm{NO}_{3}, \mathrm{ICPDR}$ and ECE have the same standard limits.

compared to the wet season. Water temperatures exhibited a significant seasonal cycle (t test, p-value $<0.05)$, whereby the highest value $\left(28^{\circ} \mathrm{C}\right)$ was recorded at S3 and $\mathrm{S} 4$ during the dry season and the lowest value $\left(6^{\circ} \mathrm{C}\right)$ was measured at S1 and S2 in February during the wet season. As for the $\mathrm{pH}$ measurements, no significant variability was detected between the two seasons. The median for EC concentrations in the dry season was $449 \mu \mathrm{S} / \mathrm{cm}$, which was around 2 times higher than the median recorded during the wet season. This variation between seasons was significant (Wilcoxon, $p$-value $<0.05$ ) and is to be expected as flows in the dry season tend to be low and heavily influenced by anthropogenic discharges. Similarly, 
the difference in TN levels between the two seasons was significant (Wilcoxon, p-value $<0.05)$, with the highest TN concentration $(29.1 \mathrm{mg} / \mathrm{L})$ measured at S4 in November during the dry season and the lowest concentration $(0.01 \mathrm{mg} / \mathrm{L})$ recorded at $\mathrm{S} 1$ in March during the wet season. The median TN concentration during the dry season was almost 5 times higher than the median recorded for the wet season. A similar seasonal pattern was observed for TP concentrations, with the highest concentration $(4.92 \mathrm{mg} / \mathrm{L})$ measured at $\mathrm{S} 4$ on the $2 \mathrm{nd}$ of June (dry season) as compared to the lowest concentration $(0.01 \mathrm{mg} / \mathrm{L})$, which was recorded at $\mathrm{S} 2$ on the 12th of December in the wet season. Sulfates concentrations ranged between 60 and $88 \mathrm{mg} / \mathrm{L}$ during the dry season and between 20 and $70 \mathrm{mg} / \mathrm{L}$ in the wet season. TSS values were also found to be significantly higher ( $\mathrm{t}$ test, $\mathrm{p}$-value 0.04 ) during the dry season as compared to the wet season. Similarly, the concentrations of COD exhibited a significant seasonal pattern (Wilcoxon, p-value 0.001) whereby the median concentration in the dry season was 6.5 times higher than the median concentration of COD during the wet season. On the other hand, the seasonal pattern of the BOD concentrations was less evident (Wilcoxon, p-value 0.02) as compared to that associated to COD levels, however the median BOD concentration during the dry season was 6 times higher than that associated with the wet season. The fact that all pollution levels dropped in the wet season as compared to the dry season indicates that dilution in the Beirut River plays a dominant role in modulating pollution levels in agreement with several studies [15], [24], [26], [27]. This highlight that the basin is overwhelmingly dominated with point source pollution namely from industrial and domestic wastewater discharge and that non-point sources play a minimal role.

To further analyse the potential for an interaction of space and time on the pollution levels, a two-way ANOVA was performed for each tested parameter. It was noted that for all the tested parameters (TN, TP, TSS, Temperature, BOD, COD, and electrical conductivity) no significant interaction was observed. Only $\mathrm{pH}$ levels were found to be affected by spatiotemporal interaction ( $\mathrm{p}$-value for interaction $<0.05$ ), whereby $\mathrm{pH}$ levels were similar across the 4 stations in the wet season but showed large variability in the dry season, with station $\mathrm{S} 4$ showing a significantly higher $\mathrm{pH}$ level as compared to the remaining three stations.

A closer look at the correlations between the different pollutants and flow was conducted for both the wet (a) and the dry (b) season (Fig. 6). While most parameters exhibited a negative correlation with flow in the wet season, an indication of a decrease in pollutant concentrations as flow increases, only TSS showed a positive correlation. This is probably attributed to the higher erosion rates following high intensity rain events. In the dry season, $\mathrm{pH}, \mathrm{TN}, \mathrm{NO}_{2}$, and $\mathrm{SO}_{4}$ exhibited a positive correlation with flow. A significant (p-value 0.001 ) positive correlation was found between TN and TP in the wet season; yet the correlation weakened in the dry season. This is indicative that the pollution sources of both $\mathrm{TN}$ and TP are similar during in the wet season; yet the pollutant loads and/or uptake appear to differ in the dry season.

\section{CONCLUSION}

Form the results obtained, the following conclusions can be drawn:

- The Beirut River water quality is in violation of most ambient water quality standards and as such its designated uses are compromised.

- The deterioration of the water quality across the basin showed a strong spatial pattern, with the water quality getting consistently worst moving from the headwaters down to the discharge point. This highlights the negative role that the river has on the coastal water quality around its discharge point to the Mediterranean Sea. 

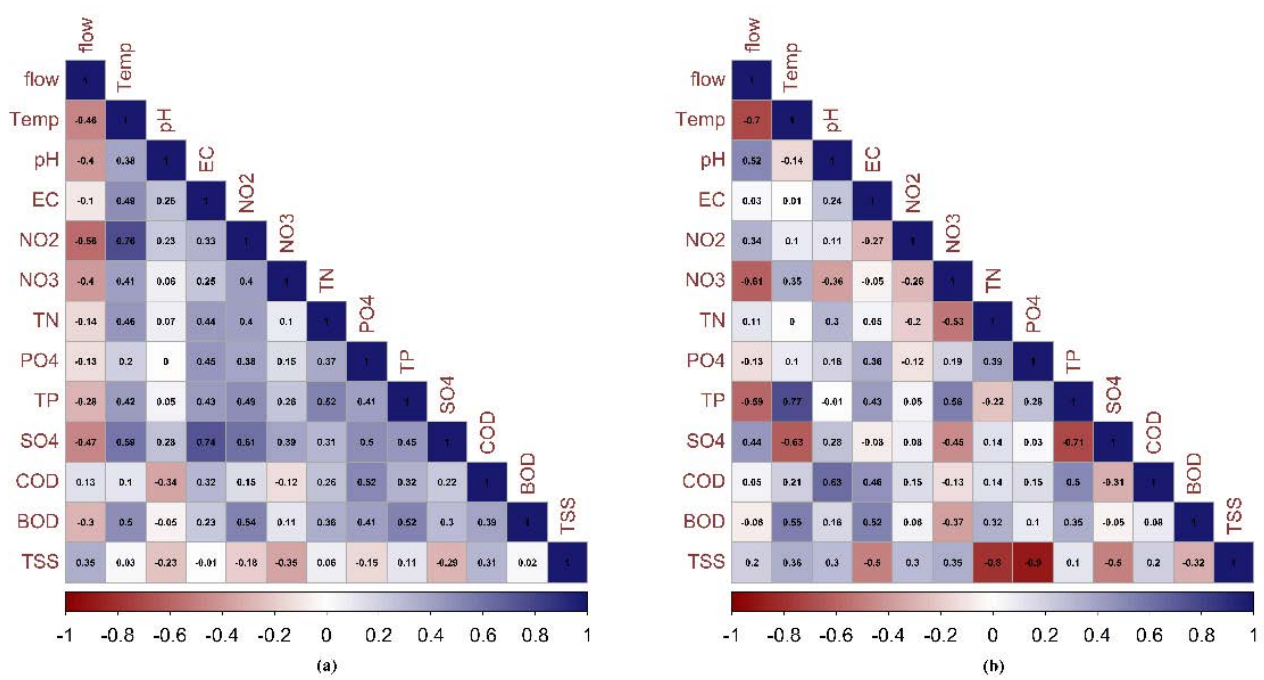

Figure 6: Spearman's rank correlations between the measured parameters during the wet and dry season. (a) Wet season; (b) Dry season.

- While all tested water quality parameters exceeded the standard limits during both the wet and dry season, the highest levels of pollution were consistently observed during the dry season, when the flow in the river was low.

- The observed negative relationship between flow and the different measured pollutants indicates that the main sources of pollution in the Beirut River are point sources emerging from anthropogenic activities all along its watershed. Among these sources, the discharge of domestic and industrial wastewater appear to be the leading sources of impairment all along the river.

- There is an urgent need to develop and implement a basin-wide management plan that aims to limit the fast and unplanned urbanization of the Beirut River while also implementing the national wastewater treatment plan that has been proposed by the Ministry of Energy and Water.

- Future work should focus on developing a detailed water quality model for the basin so as to further characterize and map pollutant hotspots all along the basin.

\section{REFERENCES}

[1] Carpenter, S.R., Stanley, E.H. \& Vander Zanden, M.J., State of the world's freshwater ecosystems: physical, chemical, and biological changes. Annual review of Environment and Resources, 36, pp. 75-99, 2011.

[2] Balter, M., Archaeologists say the 'Anthropocene' is here-but it began long ago. Science, 340(6130), pp. 261-262, 2013.

[3] Da Silva, A.M.M. \& Sacomani, L.B., Using chemical and physical parameters to define \&the quality of Pardo River water (Botucatu-SP-Brazil). Water Research, 35(6), pp. 1609-1616, 2001.

[4] Meybeck, M., Global analysis of river systems: from Earth system controls to Anthropocene syndromes. Philosophical Transactions of the Royal Society B: Biological Sciences, 358(1440), pp. 1935-1955, 2003. 
[5] Vörösmarty, C.J. et al., Fresh water. Millennium ecosystem assessment, 1, pp. 165207, 2005.

[6] Vörösmarty, C.J. et al., Global threats to human water security and river biodiversity. Nature, 467(7315), pp. 555-561, 2010.

[7] UN, Water: A Matter of Life and Death. Fact sheet. International Year of Freshwater 2003: United Nations, 2003.

[8] Rissman, A.R. \& Carpenter, S.R., Progress on nonpoint pollution: Barriers \& opportunities. Daedalus, 144(3), pp. 35-47, 2015.

[9] Simeonov, V. et al., Assessment of the surface water quality in Northern Greece. Water research, 37(17), pp. 4119-4124, 2003.

[10] Kepner, W.G., Semmens, D.J., Bassett, S.D., Mouat, D.A. \& Goodrich, D.C., Scenario analysis for the San Pedro River, analyzing hydrological consequences of a future environment. Environmental Monitoring and Assessment, 94(1-3), pp. 115-127, 2004.

[11] Caccia, V.G. \& Boyer, J.N., Spatial patterning of water quality in Biscayne Bay, Florida as a function of land use and water management. Marine Pollution Bulletin, 50(11), pp. 1416-1429, 2005.

[12] Zhang, M.-K., Wang, L.-P. \& He, Z.-L., Spatial and temporal variation of nitrogen exported by runoff from sandy agricultural soils. Journal of Environmental Sciences, 19(9), pp. 1086-1092, 2007.

[13] Massoud, M.A., El-Fadel, M., Scrimshaw, M.D. \& Lester, J.N., Factors influencing development of management strategies for the Abou Ali River in Lebanon: I: Spatial variation and land use. Science of the Total Environment, 362(1), pp. 15-30, 2006.

[14] Bu, H., Tan, X., Li, S. \& Zhang, Q., Temporal and spatial variations of water quality in the Jinshui River of the South Qinling Mts., China. Ecotoxicology and Environmental Safety, 73(5), pp. 907-913, 2010.

[15] Massoud, M.A., El-Fadel, M., Scrimshaw, M.D. \& Lester, J.N., Factors influencing development of management strategies for the Abou Ali River in Lebanon II: Seasonal and annual variation. Science of the Total Environment, 362(1-3), pp. 31-41, 2006.

[16] Crosa, G., Froebrich, J., Nikolayenko, V., Stefani, F., Galli, P. \& Calamari, D., Spatial and seasonal variations in the water quality of the Amu Darya River (Central Asia). Water Research, 40(11), pp. 2237-2245, 2006.

[17] Sarkar, S.K., Saha, M., Takada, H., Bhattacharya, A., Mishra, P. \& Bhattacharya, B., Water quality management in the lower stretch of the river Ganges, east coast of India: an approach through environmental education. Journal of Cleaner Production, 15(16), pp. 1559-1567, 2007.

[18] Zhou, F., Huang, G.H., Guo, H., Zhang, W. \& Hao, Z., Spatio-temporal patterns and source apportionment of coastal water pollution in eastern Hong Kong. Water Research, 41(15), pp. 3429-3439, 2007.

[19] Houri, A. \& El Jeblawi, S.W., Water quality assessment of Lebanese coastal rivers during dry season and pollution load into the Mediterranean Sea. Journal of Water and Health, 5(4), pp. 615-623, 2007.

[20] MOE/UNDP/ECODIT, SOER (State of the Environment). Chapter 3: Water Resources, Lebanon, 2011.

[21] Rice, E.W. \& Bridgewater, L., Water Environment F, American Water Works A, American Public Health A. Standard methods for the examination of water and wastewater, Washington, D.C: American Public Health Association, 2012.

[22] R Core Team, R: A Language and Environment for Statistical Computing, Vienna, Austria: R Foundation for Statistical Computing, 2017. 
[23] Wu, Y. \& Chen, J., Investigating the effects of point source and nonpoint source pollution on the water quality of the East River (Dongjiang) in South China. Ecological Indicators, 32, pp. 294-304, 2013.

[24] Chang, H., Spatial analysis of water quality trends in the Han River basin, South Korea. Water research, 42(13), pp. 3285-3304, 2008.

[25] Brodie, J.E., Scientific Consensus Statement: Land Use Impacts on the Great Barrier Reef Water Quality and Ecosystem Condition: Reef Water Quality Protection Plan Secretariat, 2013.

[26] Vega, M., Pardo, R., Barrado, E. \& Debán, L., Assessment of seasonal and polluting effects on the quality of river water by exploratory data analysis. Water research, 32(12), pp. 3581-3592, 1998.

[27] Alberto, W.D., del Pilar, D.M., Valeria, A.M., Fabiana, P.S., Cecilia, H.A. \& de los Ángeles, B.M., Pattern recognition techniques for the evaluation of spatial and temporal variations in water quality. a case study: Suquía River Basin (CórdobaArgentina). Water Research, 35(12), pp. 2881-2894, 2001. 